\title{
Motivation, engagement, attitudes and buying intent of female Facebook users
}

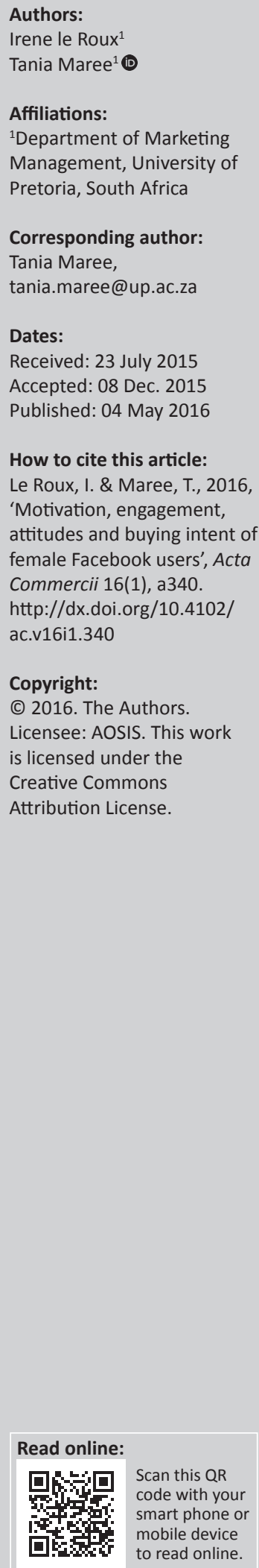

Orientation: This research examined the influence of motives and engagement on brand attitudes and the influence thereof on buying intentions in the context of online social media brand communities.

Research purpose: The primary purpose was to investigate the interrelationship between motives, engagement, brand attitudes and buying intent of female Facebook brand apparel community members in South Africa.

Motivation for the study: Social media created a new tool for marketers to break through advertising clutter. Scholars assert that the influence of social media brand communities on consumers' attitudes, behaviour and intentions need to be studied, and such research should be applied to a specific industry.

Research design, approach and method: A total of 333 female apparel brand community members on Facebook completed a quantitative, structured online survey. Structural equation modelling (SEM) was used to investigate the interrelationship between the constructs.

Main findings: The results indicated significant relationships between some of the hypothesised constructs, namely hedonic motives and brand attitude, as well as brand attitude and buying intention.

Practical/managerial implications: The findings suggested marketers should create entertaining and useful brand community experiences, as that would lead to favourable attitudes, and positively influence buying intention. Suggestions for marketers to use this platform effectively to engage community members were provided.

Contribution: The research contributed to the limited knowledge on brand community behaviour on Facebook in an emerging market context. This research examined female consumers, an influential segment of social media users. It provided empirical support for the theoretical relationship between brand attitude and buying intention.

\section{Introduction}

Modern consumers have grown sophisticated and discerning as a result of being exposed to a myriad of information through various marketing media. In particular, the social media phenomenon has played a large role in how consumers think, act and behave towards brands. According to Goldstuck (2012:1), South Africa's social media profile is unique as social media use has crossed the age barrier and urban/rural divide; Facebook has '[gone] mainstream in South Africa'.

This platform, which is the world's most popular social networking site (SNS), was reported to have 1.44 billion active monthly users at the end of March 2015 (Facebook 2015). According to WebAfrica (2015) there are 11.8 million Facebook users in South Africa. This constitutes a large group of consumers who may be reached through non-traditional marketing media. Ulusu (2010:2956) suggests that in countries where the use of social media is emerging and growing (such as in South Africa), further research is crucial in order to understand social networking and consumer behaviour.

Scholars argue that the social media are replacing traditional media in many ways, creating a new marketplace and a new tool for marketers (Akar \& Topcu 2011; Bruhn, Schoenmueller \& Schafer 2012; Mangold \& Faulds 2009). Social media have changed the way organisations interact with their consumers. Algesheimer, Dholakia and Herrmann (2005:31) assert that online brand communities have gained increased interest from researchers as it is a way for marketers to break through the cluttered marketing environment. Researchers argue that the potential influence of 
these communities on consumers' attitudes, behaviour and intentions should be investigated. Furthermore Chen et al. (2008:6) suggest that research into social media should be applied to a specific industry. This study addressed the suggestion by focusing on the apparel industry.

To answer these calls for further and more focused research, this article reports on research conducted amongst a South African sample of Facebook users, focusing on how consumer motivation and engagement interrelate with brand attitudes and, ultimately, buying intent in an online brand community context. In order for organisations to invest in brand community building over and above other traditional marketing tools, it is also important to understand how engagement in brand communities influences customer attitudes and behaviour (Algesheimer et al. 2005:19). According to Pöyry, Parvinen and Malmivaara (2013:226), consumption motives (both hedonic and utilitarian) determine consumer usage behaviours. Customer engagement and interaction with a brand, which is driven by motivation, enhances the brand value experience, which can have a positive effect on brand attitude (Gummerus et al. 2012:858). A positive attitude will in turn influence a consumer's buying intention, as proposed by the theory of planned behaviour (TPB) (Ajzen 2001:43; Alvandi, Fazil \& Amiri 2014:118), which contributes to the theoretical basis for the study.

The members engaged in Facebook brand communities for a specific industry (fashion apparel) were targeted for this study. The specific context was Facebook brand communities of popular female fashion brands (clothing and accessories), as many of these brands are ranked amongst the top 100 most popular brands on Facebook (Socialbakers 2013). Women are the fastest growing group on most social networks and outnumber men two to one on Facebook (Beckbessinger 2011:12; Kietzmann et al. 2011:243). Additionally, previous research points out that women spend about $10 \%$ more time on social network sites than men (Haferkamp et al. 2012:92). According to Akar and Topcu (2011:49) women are more engaged in SNSs than men, suggesting that they may wield a stronger influence on peers.

The research used an online structured survey of female Facebook users, who were apparel brand community members. The instrument was based on existing measures and adapted to the online environment. Contrary to the information in the literature on the topic (Habibi, Laroche \& Richard 2014; Pöyry et al. 2013), the study's results did not indicate a positive relationship between customer engagement and motives or brand attitude. It supported the theoretical link between brand attitude and buying intentions, and indicated a positive relationship between hedonic motives and brand attitude.

\section{Contribution to the field}

This research contributes to the existing body of knowledge on consumer social media behaviour and specifically examines interrelationships between consumer behaviour constructs in the context of female consumers, who are a growing and influential segment of social media users. It provides insight into brand community members' behaviour, which allows marketers the opportunity to fine-tune their approaches to use this platform effectively as a marketing communication tool.

The rest of the article is structured as follows: the research objectives are stated, followed by a literature and theoretical background and stated hypotheses. Subsequently, the research method and results are described. This is followed by the discussion and managerial implications are provided. It concludes by examining limitations and offers recommendations for future research.

\section{Objectives}

The primary objective of the study was to investigate the interrelationship between motives, engagement, brand attitudes and buying intent of female Facebook brand apparel community members in the emerging market of South Africa. The secondary research objectives included, inter alia, determining the respondents' motives for joining brand communities on Facebook, their engagement levels, brand attitudes and buying intentions.

\section{Literature review Social media research landscape}

Social media research has been growing in importance as scholars have seen the impact of social media on society and consumers (Khang, Ki \& Ye 2012:279). A variety of topics has been researched since the rise of social media in the late 1990s, ranging from examining network structure to investigating general social media usage.

According to Zhang and Leung (2014:6), who reviewed SNSrelated articles published in high-profile communication journals, common themes found across these studies included impression management, networks and their structures, associations between on- and offline networks, privacy issues, as well as several relational examinations such as romantic and even organisational relationships. The attributes of SNS users and their needs as pertaining to the use of SNS have also been examined, often from a psychological perspective. Social media usage patterns and how they are used as a tool of communication have also enjoyed research attention. Khang et al. (2012:287) identified that social media used as a marketing or advertising tool was the most prevalent topic in journals focusing on marketing.

Despite the growth in research on social media over the last decade, there are still calls for more research in this field, particularly for more focused research on buying intention and behaviour. Zhang and Leung (2014:10) argued for researchers to investigate 'the roles and impacts of networks', as SNS by definition incorporates social communication amongst networks. Brand communities on social networks constitute a network within the platform, making them suitable for investigation. Khang et al. (2012:293) point out the 
lack of studies that suggest improvements to social media, as may be achieved by examining social media consumer behaviour in a specific context. There is also limited research amongst older consumers, as many researchers focused on students or young adults. This research aimed to include a wider age range by not specifically targeting students.

Additionally, much of the currently published research on SNS has been conducted in Western cultures, particularly USA and European contexts (Zhang \& Leung 2014:13). This allows opportunity for studies focusing on non-Western contexts and supports further research in, for example, an African context. This research study has attempted to fill some of that gap by studying South African users.

\section{Social media: An overview}

Social media, a group of Internet-based applications, are considered tools of communication that enable people to gather and share information, knowledge and opinions (Erdogmus \& Cicek 2012:1354). This in turn has become a key influencer of consumer behaviour in terms of attitudes, purchase and post-purchase behaviour and evaluation of brands (Mangold \& Faulds 2009:358). The value of social media as an interactive marketing communication tool is thus evident. This is further supported by Goldstuck (2015:4) who indicates that $73 \%$ of South African brands surveyed plan to roll out content marketing strategies during 2016.

Within social media, different applications exist. SNSs may be defined as social media applications that allow members to connect to others by the creation of personal profiles to which friends or colleagues can be invited to have access (Kaplan \& Haenlein 2010:60). Research indicates that users spend approximately 30 minutes per day on Facebook and $\log$ in more than once a day (Kane, Chiru \& Ciuchete 2012:161). According to BlueMagnet (2015), South African users check their newsfeeds 15 times a day, on average.

The activities that consumers usually become involved in on SNSs include creating or consuming content that other users have created (Coulter \& Roggeveen 2012:878). This suggests that people are involved in the platform and that it forms part of their daily routine; this is good news for marketers looking to present their brands through this medium. According to Akar and Topcu (2011:40), consumers enjoy sharing their opinions on shopping experiences as well as making more purchase decisions online by reading about products.

Facebook is envisioned to become one of the most regularly used tools for conducting business activities and many organisations plan to increase their presence on the platform (Pöyry et al. 2013:224). One way in which this can occur is through brand pages, also referred to as brand communities. These brand pages are a commonly used social media channel for marketing and are useful as one of the major avenues to conduct business activities, owing to the advantage of reaching large audiences with low cost (Pöyry et al. 2013:224).

\section{Online brand communities}

An online brand community can be described as a marketplace community with a shared interest in a specific brand where information on the brand's offerings can be exchanged (Kim et al. 2008:410). Muniz and O'Guinn (2001:413) first introduced the concept of brand communities, and defined them as non-geographically bound channels where consumers can interact with the brand. An online brand community enables members to show a common interest in the brand by 'liking' the page (Gummerus et al. 2012:858), thereby becoming 'fans' or followers of the brand. According to Bruhn et al. (2012:770) brand communities allow consumers to build relationships with the brand and interact with it (as well as other users or fans) on SNSs. In this way, the community becomes a credible information source. Kim et al. (2008:420) assert that the shared interests of online brand community members cause them to be potentially highly committed and loyal. They are also likely to be advocates for the brand.

According to Kane et al. (2012:162), 7\% of respondents in their study indicated that their motivation for using Facebook was to find out more about products and services. Previous research identified that some of the reasons consumers engage in a brand community are for entertainment, information, instrumental, and economic and social benefits (Dittmar, Long \& Meek 2004; Erdogmus \& Cicek 2012; Gummerus et al. 2012; Habibi et al. 2014; McAlexander, Schouten \& Koenig 2002).

\section{Background: Theoretical foundations}

This study focused on the factors that interact to influence the buying intention of female Facebook brand community users. Previous literature suggests interrelationships amongst motivation, engagement and attitudes and that consumer brand attitudes influence consumer buying intent and, ultimately, behaviour (Bruhn et al. 2012; Chen et al. 2008; Pöyry et al. 2013; Wirtz et al. 2013).

\section{Motivation}

Researchers have studied two categories of motives in an online context, namely, hedonic and utilitarian motives (Babin, Darden \& Griffin 1994; McAlexander et al. 2002; Pöyry et al. 2013) These are grounded in self-determination theory by Ryan and Deci (2000:55), who differentiate these as intrinsic (hedonic) and extrinsic (utilitarian) motives. Hedonic motives refer to fun seeking, playfulness, leisure, excitement, spontaneity, social involvement and enjoyment, whilst utilitarian motives refer to efficiency and effectiveness, accomplishment, rational behaviour and goal-seeking (Babin et al. 1994:644; Dittmar et al. 2004:424). Thus, hedonic motives relate to what consumers find enjoyable and utilitarian ones to what is useful or functional to the individual. Previous research has indicated motives to be influencers of attitudes (Mir 2014) and engagement in online contexts (Dittmar et al. 2004; Pöyry et al. 2013). 


\section{Consumer attitudes}

Lien and Cao (2014:105) refer to attitudes as learned positive or negative summative evaluations that develop over time and lead to consumers' like or dislike of brands. Attitudes are learned through experiences with a product or from information received or acquired from mass media or individuals. Once this learned predisposition is recalled, it influences behaviour and decision-making (Bagozzi \& Dholakia 2006:50). Predicting behaviour based on attitude, which draws upon Ajzen's TPB, has been a common occurrence in many studies (Ajzen 2001:43). The TPB holds that a favourable attitude will lead to a favourable buying intention and ultimately to actual buying behaviour.

Ajzen (2001:33) states that continuous exposure to stimuli can lead to a favourable evaluation or liking of the stimuli. This is supported by Akar and Topcu (2011:50), who assert that familiarity of a stimuli or medium tends to lead to a more favourable attitude. This process happens spontaneously without consumers realising it. The evaluation of an object based on attributes (such as good-bad; pleasant-unpleasant) is often used to measure attitudes (Ajzen 2001:28).

\section{Customer engagement}

Customer engagement encompasses actions that transcend transactional behaviours stemming from motivational forces (Van Doorn et al. 2010:254). Consumers engage in behaviours such as recommendations, helping other consumers, writing reviews, joining an online discussion, commenting on posts, searching for information and participating in competitions or online surveys (Gummerus et al. 2012:857; Wirtz et al. 2013:229). It represents an inherently relational approach towards the organisation.

Theoretically speaking, Brodie et al. (2011:253) suggest that customer engagement finds its conceptual basis in the relationship marketing paradigm as it focuses on '... interactive experience and value co-creation in marketing relationships.' Vargo (2009:375) supports the relational view by arguing that the service-dominant (SD) logic is appropriate to conceptualise organisational-consumer relationships owing to the interactive and reciprocal value co-creation that occurs. Consumer behaviour is, therefore, focused on the interactive, co-creating experiences with other consumers or stakeholders (Brodie et al. 2013:106).

Engagement can manifest itself in purchase behaviour as well as non-purchase behaviour, such as commenting on or liking posts (Gummerus et al. 2012:858). This essentially stimulates online word-of-mouth communication and can have a big impact on peers. A customer can engage with the brand and contribute value without purchasing, by giving positive news and opinions which have the potential to influence other users of the brand community (Kumar et al. 2010:298).

\section{Buying intention}

According to Ajzen (2001:43) and Foxall and Goldsmith (1994:99), intention is a fairly accurate predictor of behaviour and is a function of attitude and subjective norms. This refers to the TPB view, which postulates that intentions are the closest determinant of behaviour (Darvell, Walsh \& White 2011:718). Chen et al. (2008:3) refer to buying intention as an effort or tendency to purchase a product or brand. Therefore, if a consumer has a strong intention to purchase the consumer is more likely to make a purchase.

\section{Conceptual framework and hypotheses}

Based on the foregoing, a conceptual model of the relationships amongst motivation, customer engagement, attitude and buying intention has been constructed (refer to Figure 1).

Mir (2014:49) found a significantly positive relationship between utilitarian (extrinsic) motivation and attitudes. Similarly, Lien and Cao (2014:108) indicated that motivations (entertainment as well as informational) were significant predictors of attitudes. According to Ajzen (2001:29), people's motivations lead to the retrieval of a specific attitude and different attitudes towards the same object can form in different contexts. Consequently, the following hypotheses were formulated:

H1: hedonic motives have a positive effect on users' brand attitudes.

H2: utilitarian motives have a positive effect on users' brand attitudes.

Zaglia (2013:221) points out that consumers are motivated to participate in or engage with brand communities in order to acquire, amongst others, useful product skills and knowledge, as well as for social and entertainment purposes. These relate to utilitarian and hedonic motives. Pöyry et al. (2013:225) argue that both these types of motivation are important in explaining behaviour on Facebook. Furthermore, such motives are indicative of consumers' future brand community engagement behaviour (Habibi et al. 2014:154). Accordingly, the following hypotheses were set:

H3: hedonic motives have a positive effect on customer engagement.

H4: utilitarian motives have a positive effect on customer engagement.

According to Vivek, Beatty and Morgan (2012:136), consumers who are engaged may display more positive brand attitudes

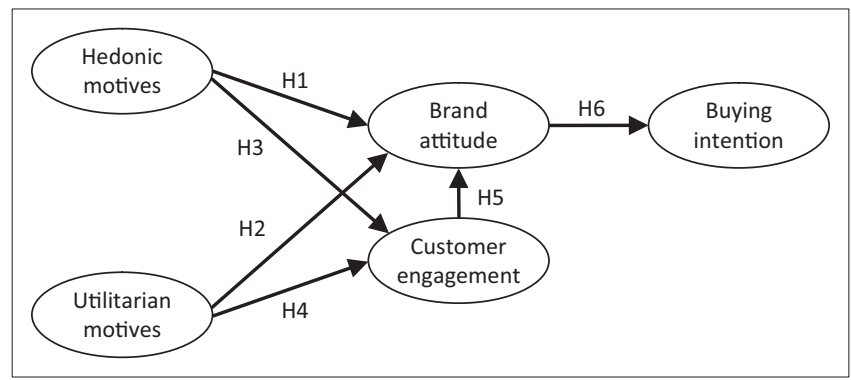

Source: Authors own work

FIGURE 1: Conceptual framework. 
associated with the engagement (for example, on a brand community). Further outcomes of engagement are a strengthened brand, an increase in brand loyalty and a favourable influence on attitudes and behaviours towards the brand (Wirtz et al. 2013:234-235). Based on this, the following hypothesis was formulated:

H5: customer engagement has a positive effect on brand attitude.

Brand attitude has a strong influence on buying intention and is one of the main determinants thereof (Bruhn et al. 2012:776; Chen et al. 2008:3). This is also supported by Ajzen's (2001:43) assertion that attitude influences behavioural intent. Thus the following hypothesis was formulated:

H6: brand attitude has a positive effect on buying intention.

\section{Methodology}

An online research panel (Consulta Panel) was used to collect data from adult female users of Facebook apparel brand communities (for example, Woolworths, Zando, and $\mathrm{Mr}$ Price, amongst others) in South Africa. These include active participants as well as browsers. The Consulta Panel has 46000 members, of whom $51 \%$ are female. A panel is a group of potential participants who previously indicated that they would be willing to participate in research studies (Cooper \& Schindler 2006:714). The Consulta group of panel members is considered representative of the adult South African population in terms of access to Internet services, and were thus suitable for the purpose of the study.

Every female panel member of the panel (regardless of age and province) has an equal chance of being selected, which represents a simple random approach to sampling. The survey was distributed to all female members of the panel, of whom 771 started the survey. Some were filtered out as a result of not being eligible and some dropped out for unknown reasons. Finally, a total of 333 usable questionnaires were completed by respondents. For structural equation modelling (SEM) studies, a sufficiently large sample is required. Kline in Lei and Wu (2007:34) recommends a sample size exceeding 200.

Data were collected via online self-administered questionnaires. Participants were recruited by uploading a list of email addresses chosen from the Consulta Panel to which the email invitation was sent. A link was provided in the invitation that directed the respondent to the online survey. All required ethical considerations were adhered to and informed consent was obtained before respondents commenced with the survey. The questionnaire featured six sections. The first section included screening questions to determine whether the respondent was eligible to participate in the survey. Screening questions included, inter alia, determining whether the respondent was an active member of an apparel brand community on Facebook. The second section determined habits and use of Facebook.

The following sections measured the constructs of the study, namely customer engagement, motives for joining a Facebook apparel brand community (hedonic and utilitarian), brand attitudes and buying intentions. The response format and sources from which the measures were adapted are presented in Table 1.

The last section in the questionnaire collected demographic information about the respondents.

The questionnaire was pretested amongst 130 online Consulta Panel members and the results indicated that no major changes to the questionnaire were necessary. The pre-test was also used to investigate the reliability of the scales used to measure the constructs of this study. All the Cronbach's alpha values were larger than 0.7 .

Descriptive analyses were carried out on the final data collected and an exploratory factor analysis (EFA) was conducted to evaluate construct and discriminant validity of the measurement scales used in the study. This was carried out although existing measures were used, owing to the uniqueness of this study context (non-Western, female-only and industry focused), which may cause different results from those obtained in previous, Western studies. Thus the EFA was deemed most appropriate for this purpose.

Subsequently, SEM was used to test the fit of the proposed model (Figure 1) using Amos software. According to Nusair and Hua (2010:316), SEM is best suited when a study deals with multiple latent constructs, where each construct is represented by several measurable variables. Descriptive statistics were calculated to describe the demographic profile of respondents as well as their Facebook usage behaviour. The article also reports the descriptive statistics (means and standard deviations) for respondents' motives for joining brand communities, overall brand attitude, customer engagement, and buying intentions.

\section{Results \\ Descriptive statistics}

The distributions of age, race groups and province of origin of the respondents follow (Table 2).

TABLE 1: Measures for constructs.

\begin{tabular}{lll}
\hline Construct & Response format & Source \\
\hline Customer engagement & Five-point Likert $(1=$ Never to $5=$ Regularly) & Gummerus et al. (2012) \\
Motives & Seven-point Likert $(1=$ Completely disagree to $7=$ Completely agree $)$ & Babin et al. (1994); Pöyry et al. (2013) \\
Brand attitudes & Seven-point Likert $(1=$ Completely disagree to $7=$ Completely agree) & Spears and Singh (2004) \\
Buying intention & Seven-point Likert $(1=$ Very low to $7=$ Very high) & Dodds, Monroe and Grewal (1991) \\
\hline
\end{tabular}

Source: Authors own work 
TABLE 2: Demographic profile of respondents.

\begin{tabular}{|c|c|c|}
\hline Variable & $n$ & $\%$ \\
\hline \multicolumn{3}{|l|}{ Age } \\
\hline No answer & 1 & 0.3 \\
\hline Between 18 years and 25 years old & 29 & 8.7 \\
\hline Between 26 years and 35 years old & 124 & 37.2 \\
\hline Between 36 years and 45 years old & 82 & 24.6 \\
\hline Between 46 years and 55 years old & 63 & 18.9 \\
\hline Between 56 years and 65 years old & 27 & 8.1 \\
\hline$>65$ years old & 7 & 2.1 \\
\hline \multicolumn{3}{|l|}{ Race $\dagger$} \\
\hline White people & 199 & 59.8 \\
\hline African & 70 & 21.0 \\
\hline Mixed race & 43 & 12.9 \\
\hline Indian & 16 & 4.8 \\
\hline Prefer not to say & 3 & 0.9 \\
\hline Asian & 2 & 0.6 \\
\hline \multicolumn{3}{|l|}{ Province } \\
\hline Gauteng & 200 & 60.1 \\
\hline Western Cape & 63 & 18.9 \\
\hline KwaZulu-Natal & 34 & 10.2 \\
\hline Eastern Cape & 10 & 3.0 \\
\hline Limpopo & 8 & 2.4 \\
\hline North-West & 8 & 2.4 \\
\hline Mpumalanga & 4 & 1.2 \\
\hline Northern Cape & 4 & 1.2 \\
\hline Free State & 2 & 0.6 \\
\hline
\end{tabular}

Source: Authors own work

$\dagger$, Racial classification in the questionnaire was operationalised according to Statistics South Africa. Mixed race people in the South African context are defined as '... a person of mixed White and non-White descent' (Pollard \& Liebeck 1994).

Table 2 shows that the majority (80.7\%) of the respondents are between the ages of 26 and 55. This indicates a wider age range than is often reported in existing research. The majority $(60 \%)$ of the respondents are white people, which is comparable to the national figures for access to the Internet (Omnicum Media Group [OMD] 2014). The majority of respondents reside in Gauteng (60\%). According to Goldstuck (2015:53), Facebook use showed the highest urban growth in Johannesburg and Pretoria in the Gauteng province in 2014.

\section{Facebook usage and behaviour}

Respondents were requested to indicate how long they had been using Facebook, as well as the duration of their use of Facebook per day. The majority $(77 \%)$ of respondents reported having used Facebook in excess of three years; only $1 \%$ had been using Facebook for less than six months. This represents a sample that is experienced in using the platform. Usage frequency (in terms of number of hours spent) was also measured (refer to Figure 2).

Figure 2 shows that $40 \%$ of respondents spend between one and three hours daily on Facebook, followed by 39\% who spend less than one hour on Facebook per day. Cumulatively, $61 \%$ of the respondents use the platform for an hour or more per day, indicating high usage frequency.

Respondents were also required to indicate how they use the Facebook brand community page that they selected (fivepoint scale, $1=$ never to $5=$ always). The results suggest a

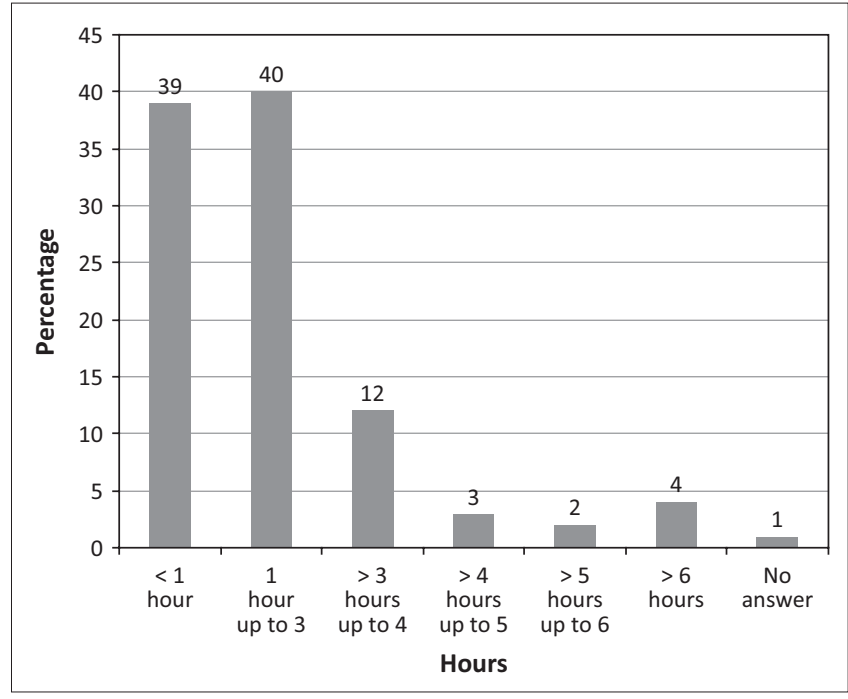

Source: Authors own work

FIGURE 2: The number of hours spent on Facebook daily.

moderate to low level of activity on their chosen brand community page. The majority of respondents (27.3\%) indicated that they 'sometimes' visited the brand community page. Thirty-three per cent 'sometimes' read messages and $36.3 \%$ 'sometimes' like content on the page. The majority 'never' writes comments.

\section{Exploratory factor analysis}

Each construct was subjected to a separate EFA to assess the unidimensionality of the scales measuring the dependent and independent variables. Exploratory factory analysis, using maximum likelihood estimation as extraction method and oblique rotation (Promax) was conducted using SPSS. Maximum likelihood is appropriate for random samples (Field 2013:674) and oblique rotation was used as the factors are assumed to be correlated (Hair et al. 2014:114). For each construct, the Kaiser-Meyer-Olkin (KMO) measure of sampling adequacy and Bartlett's test of sphericity were considered in determining the appropriateness of the data for factor analysis. The KMO values were hedonic motives 0.907 , utilitarian motives 0.578 , customer engagement 0.659 , brand attitude 0.846 and buying intention 0879 . These $\mathrm{KMO}$ values exceeding 0.500 and statistically significant values for Bartletts' test of sphericity $(p<0.05)$ indicated that factor analyses were appropriate for all constructs (Hair et al. 2014:103; Pallant 2005:182).

Factor loadings $<0.40$ are considered weak and factor loadings equal to or $>0.60$ are considered strong (CabreraNguyen 2010:102). None of the loadings was below 0.4 (refer to Table 3), indicating that all the items related to specific constructs had acceptable factor loadings (most can be considered strong).

It should be noted that the utilitarian construct (originally consisting of four items) unexpectedly resulted in a twofactor solution. However, two of the items (the reverse scored items, which were recoded before analysis) reflected very low communalities. This resulted in a Hessian that was not 
TABLE 3: Factor loadings.

\begin{tabular}{|c|c|c|c|}
\hline Construct & Variance explained $\%$ & Elements & Factor loading \\
\hline \multirow[t]{7}{*}{ Hedonic motivation } & 69.121 & Compared to other things I could have done, the time spent on this page was truly enjoyable & 0.891 \\
\hline & & I enjoyed being immersed in exciting new products displayed on the page & 0.853 \\
\hline & & During the visit to the page, I felt the excitement of hunting for new products and offers & 0.836 \\
\hline & & I continue to browse or participate on this page not because I have to but because I want to & 0.815 \\
\hline & & Whilst visiting the page, I felt a sense of adventure & 0.807 \\
\hline & & I truly enjoy visiting this brand community page & 0.767 \\
\hline & & I feel like I can escape when I visit this page & 0.715 \\
\hline \multirow[t]{2}{*}{ Utilitarian motivation } & 79.808 & Whilst visiting the page, I found just what I was looking for & 0.803 \\
\hline & & I accomplish what I want to when visiting the page & 0.733 \\
\hline \multirow[t]{3}{*}{ Customer engagement } & 66.41 & How often do you visit the brand community page? & 0.822 \\
\hline & & How often do you read messages on the page? & 0.731 \\
\hline & & How often do you like content on the page? & 0.567 \\
\hline \multirow[t]{3}{*}{ Brand attitude } & 82.064 & Pleasant & 0.913 \\
\hline & & Good & 0.857 \\
\hline & & Appealing & 0.844 \\
\hline \multirow[t]{4}{*}{ Buying intention } & 91.035 & The likelihood of purchasing products from the brand I 'like' on Facebook & 0.949 \\
\hline & & My willingness to buy products from the brand I 'like' on Facebook; Category & 0.946 \\
\hline & & My intention to buy products offered by the brand I 'like' on Facebook in the future & 0.930 \\
\hline & & The probability that I would consider buying products from the brand I 'like' on Facebook & 0.929 \\
\hline
\end{tabular}

Source: Authors own work

positive definite and also negative degrees of freedom (d.f.). Therefore the decision was made to remove these items. Only the items reflecting communalities above 0.3 were retained. These loaded on one factor.

For each of the other constructs, only one factor was extracted. Furthermore, the following items were removed because of low communalities (less than 0.3 ):

- Hedonic motives: ‘I do not see visiting the page as a good time out'.

- Customer engagement: 'How often do you write comments on the page?'

- Brand attitude: 'Unfavourable'.

\section{Reliability assessment}

Cronbach's alpha was used to calculate the internal consistency (reliability) of items used to measure each of the constructs featured in the study (refer to Table 4). Table 4 also reports the means and standard deviations of the composite scores for each of the constructs. Note that each item included was measured on a Likert-type response format ranging from 1 = strongly disagree to 7 = strongly agree.

Table 4 indicates that each construct can be considered reliable. According to Pallant (2005:92), the Cronbach alpha value should be higher than 0.7 for the scale to be considered reliable. The Cronbach alpha for customer engagement was 0.695 , but was considered acceptable as it was marginally smaller than 0.7 .

When considering the mean scores reported in Table 4, hedonic motives (M: 4.45; SD: 1.4) are prominent for the sample, as are utilitarian motives (M: 4.56, SD: 1.41). This indicates that the respondents are fairly motivated by both types of motives. Customer engagement had a midrange
TABLE 4: Cronbach's alpha values and descriptive statistics for the constructs.

\begin{tabular}{lcccc}
\hline Construct & $\begin{array}{c}\text { Number of } \\
\text { items }\end{array}$ & $\begin{array}{c}\text { Cronbach's } \\
\text { alpha }\end{array}$ & \multicolumn{2}{c}{ Descriptive statistics } \\
\cline { 4 - 5 } & & & M & SD \\
\hline Hedonic motives & 8 & 0.94 & 4.45 & 1.40 \\
Utilitarian motives & 2 & 0.747 & 4.56 & 1.41 \\
Customer engagement & 3 & 0.695 & 3.07 & 0.95 \\
Brand attitude & 4 & 0.708 & 5.57 & 1.07 \\
Buying intention & 4 & 0.967 & 5.25 & 1.51 \\
\hline
\end{tabular}

Source: Authors own work

M, mean; SD, standard deviation.

mean score (M: 3.07; SD: 0.95), indicating lower levels of engagement. The mean scores for brand attitude (M: 5.57; SD: 1.07) and buying intention (M: 5.25; SD: 1.51) are high, demonstrating that respondents have definite positive brand attitudes and high intentions of purchasing products.

\section{Structural equation modelling}

Based on the EFA results provided, which supported the construct validity of the constructs, and considering the reliability of the scales, all refined constructs were considered acceptable for inclusion in the SEM.

SEM was used to evaluate the extent to which the hypothesised structure was able to explain the relationship between dependent and independent latent variables and to estimate the magnitude of the postulated effects (Kline 2011:16). It is important to note that SEM relies on several statistics to determine the model fit (Suhr 2006:2) and the focus should not be on one fit index alone. Hair, Anderson, Tatham and Black in Schumacker and Lomax (2010:76) recommend using a combination of criteria in assessing model fit. The fit indices reported in this study are the model chi-square and Root Mean Square Error of Approximation (RMSEA) (global fit indices), and the CFI, NFI, TFI (model comparison). CFI, TLI 
and NFI values close to 0.90 or 0.95 are indicative of good or superior fit (Byrne 2010:79; Schumacker \& Lomax 2010:76). According to Hooper, Coughlan and Mullen (2008:54) and Ullman (2006:44) the recommended value of RMSEA should range between 0.05 and 0.1 , with values of 0.06 or less indicating a good model fit and up to 0.08 indicating a reasonable fit.

The model chi-square $\left(\chi^{2}: 620\right.$ 093, df: 182) was significant $(p<0.001)$. Another fit index, RMSEA of 0.08 , indicated a reasonable fit. The values of CFI, TLI and NFI were 0.929, 0.910 and 0.903 respectively, which are above 0.9 and close to 0.95 , indicating an acceptable fit. To summarise, the indices mentioned reflect the overall structural model as a reasonable fit.

Given the reasonable model fit of the overall model, it is permissible to investigate each of the structural relationships in the model. Each of the paths portrayed in Figure 3 was tested empirically.

With regard to the hypotheses formulated in this study, the researcher relied on a significance level of 0.05 . A $p$-value of less than 0.05 would therefore be regarded as statistically significant (Pallant 2005:127). The standardised regression weights $(\beta)$ are used to indicate the strength of the relationships (effect). According to Suhr (2006:5) standardised estimates below 0.1 are weak, around 0.3 are considered medium and above 0.5 are strong:

- Hypothesis 1: The results indicated that there is a statistically significant, strong positive relationship between hedonic motives and brand attitudes $(\beta=0.884$, $p=0.014)$. H1 is therefore supported.

- Hypothesis 2: No statistically significant, positive relationship was found between utilitarian motives and brand attitudes $(\beta=-0.218, p=0.537)$. H2 is not supported.

- Hypothesis 3: The results indicated no statistically significant relationship between hedonic motives and customer engagement $(\beta=0.838, p=0.128)$. H3 is therefore not supported.

- Hypothesis 4: No statistically significant relationship was found between utilitarian motives and customer engagement $(\beta=-0.496, p=0.351)$, indicating that $\mathrm{H} 4$ is not supported.

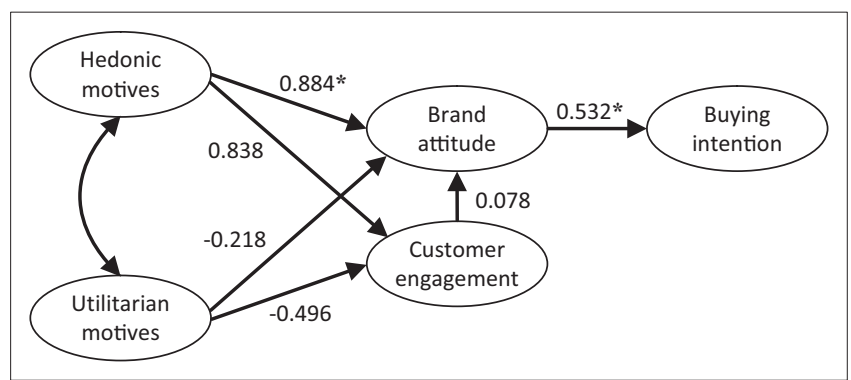

Source: Authors own work

$*$, Significant $(p<0.05)$

FIGURE 3: Structural model with standardised path coefficients.
- Hypothesis 5: The results revealed no significant relationship between customer engagement level and brand attitude ( $\beta=0.078, p=0.157)$. H5 is therefore not supported.

- Hypothesis 6: A statistically significant, positive relationship was found between brand attitude and buying intention ( $\beta=0.532, p<0.05)$, indicating that $\mathrm{H} 6$ is supported.

\section{Discussion}

This study investigated the interrelationship of motives, engagement, brand attitude and buying intention amongst female apparel brand community members. To the researchers' knowledge, it is the first study investigating the relationship between these constructs in South Africa, a nonWestern context. Measuring the influence of motives, engagement and attitude is important to predict consumers' future behaviour (Alvandi et al. 2014:126).

The descriptive results showed that the respondents were experienced Facebook users who exhibit positive brand attitudes and positive buying intentions. Their brand engagement levels were low. Although they are motivated by both hedonic and utilitarian motives, they are influenced more by utilitarian ones; similar to the findings reported by Dittmar et al. (2004:441) and Pöyry et al. (2013:231). The results of the hypothesis testing indicated that there is a significant positive relationship between hedonic motives and brand attitudes. This is similar to the findings of other studies reporting that such motives influence attitudes in a favourable way. Dittmar et al. (2004:440) found hedonicrelated motives are more likely to elicit positive attitudes from females.

There was no significant relationship between utilitarian motives and brand attitude. Although not significant, there was a negative relationship, which could indicate that usefulness might not contribute towards building positive brand attitudes.

In contrast with Habibi et al. (2014:154) and Pöyry et al. (2013:232), who found that consumers' engagement with brand community behaviour is influenced by hedonic motives, there was no significant relationship between hedonic motives and engagement in this study.

Engagement levels on the brand community were low. The literature differentiates between two types of behaviour on social media platforms, namely participation and browsing. Browsing can be defined as non-interactive behaviour, such as reading messages, whilst participation represents more interactive behaviour such as writing comments (Pöyry et al. 2013:227). The low mean score $(M=3.07)$ for customer engagement indicates that the respondents are most likely visiting the brand page primarily for reading messages, therefore they can be categorised as 'browsing' participants. Despite the low engagement levels, the respondents displayed high buying intentions for the brand that they support on Facebook. 
Contrary to previous research (Vivek et al. 2012:136) there was no significant relationship between customer engagement and brand attitude for this study. Wirtz et al. (2013:235) posited that consumers who are engaged in a brand community would be likely to display favourable attitudes towards the brand. It is possible that the low levels of engagement in this sample may have resulted in the nonsignificant relationship.

As hypothesised, the study empirically validated the strong, significant relationship between brand attitude and buying intention. This result concurs with other research (Chen et al. 2008) and theoretical foundations (Ajzen 2001). Thus, these results empirically support why brand attitude is important in social media contexts.

\section{Implications for marketers}

The results have several implications for marketers and their brand community administrators. These days, managers as well as academics recognise the importance of joining the social media trend (Weinberg \& Pehlivan 2011:275). In today's connected, online world it is necessary to meet the demand of more sophisticated consumers who act, think and behave differently towards brands (Hudson \& Thal 2013:156). For this to be achieved, managers need to understand how social media influences consumers' perceptions of and attitudes towards online brands and ultimately their buying intentions and behaviours.

This study sheds light on female consumers' motives for joining apparel brand communities, their engagement levels, brand attitudes and buying intentions, as well as the interrelationships amongst these elements. The influence of brand communities on consumer behaviour and intentions has considerable managerial value as it accentuates the importance of embracing this phenomenon and advocates building creative, informative brand communities that facilitate interaction with consumers.

The descriptive results of this research indicate that consumers join brand communities out of hedonic as well as utilitarian motives. Community members therefore seek excitement and entertainment on the one hand, but also useful and functional information on the other. In this study, the respondents reported higher levels of utilitarian motives, which suggest that informational content may play an important role within the brand community. Marketers can use this to their advantage by informing community members of promotions or new offerings. It is therefore important to keep the customer entertained as well as informed on a brand community. Goldstuck (2015:2) points to the substantial growth in consumers seeking visual content and refers to this as a 'visual revolution' in terms of online consumption in South Africa. Marketers should therefore consider incorporating creative visuals, such as video content to portray effectively both hedonic and utilitarian aspects of their brands.
Hedonic motives were also empirically shown to contribute to a favourable brand attitude, further supporting the creation of entertaining and exciting content. It is clear that brand community administrators should think carefully when designing the brand community, as well as the form of content distributed to community members. Specific actions should be taken to involve active members as part of the design process of new products and services, or to obtain their feedback and opinions. Hodis, Sriramachandramurthy and Sashittal (2015:23) support this by stating that organisations can provide better value to customers by co-opting brand communities in the creation of content.

The respondents in this study displayed low levels of engagement, suggesting that they are primarily browsers, seeking amusement and information rather than creating content or conversation. Brand community administrators should examine ways of stimulating consumer content co-creation, as previous research has shown that to be instrumental in facilitating interaction and to contribute to a favourable brand community experience. Notwithstanding the low engagement, the respondents still indicated high buying intentions. That may be attributed to the very favourable brand attitudes that the respondents hold.

\section{Limitations and recommendations for future research}

In terms of the sampling approach and data collection method, the sampling of demographic groups could not be controlled and no intervention of the researcher was possible during the survey. The demographic distribution of the sample was similar to the national Internet access statistics in terms of white and African respondents, but had low representation amongst other race groups.

Specific targeting of members of apparel brand communities who are active participants was not possible, which could account for the low overall engagement of the sample. Future research should consider specifically sampling low, medium and highly involved participants to allow a broader view. The lack of South African studies on the specific topic did not allow for comparisons to be made in the emerging market context. Lastly, the current study was limited to a single industry, namely, apparel brands.

Whilst this study contributes to the knowledge of social media brand communities, future studies should attempt to repeat the study in different industries, which will allow room for comparisons. Future research should include male brand community members to allow for gender comparisons as gender role theory suggests distinct behaviour differences between males and females.

Examining the influence of content type (entertainment, information and user generated content) on brand attitude and buying intention would also be an informative study. Steyn et al. (2011:140) point out that the identification of variables that produce a more favourable attitude in a 
social media environment is important to understand more fully the opportunities and threats of content of their brand communications. Future research could expand the investigation into more variables, such as the specific social network as an influencer, the influence of peers and previous brand experience.

\section{Conclusion}

The primary objective of the study was to investigate the interrelationships between motives, engagement, brand attitudes and buying intent of female Facebook brand apparel community members in the emerging market of South Africa. This was achieved through SEM. The significant impact of a favourable brand attitude on buying intention was validated in this study. Empirical results from the SEM suggest that brand communities have a measurable, positive impact on brand attitude and buying intentions. This confirms the importance of investing in marketing activities around building relationships with consumers on social media networking platforms. It is also important to offer consumers both entertaining and useful brand experiences within the online brand community.

\section{Acknowledgements}

The authors would like to thank Dr M. Pohl for her assistance and advice in the statistical analysis of the data.

\section{Author's contributions}

I.l.R. was a Masters' student in the Department of Marketing Management. T.M. was the study leader. The authors contributed equally to this work. T.M. was responsible for the final submitted draft of the article and acts as corresponding author.

\section{References}

Ajzen, I., 2001, 'Nature and operation of attitudes', Annual Review Psychology 52 27-58. http://dx.doi.org/10.1146/annurev.psych.52.1.27

Akar, E. \& Topcu, B., 2011, 'An examination of the factors influencing consumers' attitudes toward social media marketing', Journal of Internet Commerce 10(1) 35-67. http://dx.doi.org/10.1080/15332861.2011.558456

Algesheimer, R., Dholakia, U.M. \& Herrmann, A., 2005, 'The social influence of brand community: Evidence from European car clubs', Journal of Marketing 69, 19-34. http://dx.doi.org/10.1509/jmkg.69.3.19.66363

Alvandi, M., Fazil, S. \& Amiri, M., 2014, 'Investigating the effect of interactive media on consumer-firm relationship', International Journal of Academic Research 6(3), 118-130. http://dx.doi.org/10.7813/2075-4124.2014/6-3/b.18

Babin, B.J., Dardin, W.R. \& Griffin, M., 1994, 'Work and/or fun: Measuring hedonic and utilitarian shopping value', Journal of Consumer Research 20(40), 644-656. http:// dx.doi.org/10.1086/209376

Bagozzi, R.P. \& Dholakia, U.M., 2006, 'Antecedents and purchase consequences of customer participation in small group brand communities', International Journal of Research in Marketing 23, 46-61. http://dx.doi.org/10.1016/j.ijresmar.2006.01.005

Beckbessinger, S., 2011, 'Social media - Much more than a pretty Facebook', South African Food Review 38(7), 12-13.

BlueMagnet, 2015, The state of social media in South Africa 2014, viewed 19 January 2015 from http://www.bluemagnet.co.za/the-state-of-social-media-in-south-africa-2014/

Brodie, R.J., Hollebeek, L.D., Juric, B. \& llic, A., 2011, 'Customer engagement: Conceptual domain, fundamental propositions, and implications for research', Journal of Service Research 14(3), 252-271. http://dx.doi.org/10.1177/1094670511411703

Brodie, R.J., llic, A., Juric, B. \& Hollebeek, L., 2013, 'Consumer engagement in a virtual brand community: An exploratory analysis', Journal of Business Research 66(1), 105-114. http://dx.doi.org/10.1016/j.jbusres.2011.07.029

Bruhn, M., Schoenmueller, V. \& Schafer, D.B., 2012, 'Are social media replacing traditional media in terms of brand equity creation?', Management Research Review 35(9), 770-790. http://dx.doi.org/10.1108/01409171211255948
Byrne, B.M., 2010, Structural equation modelling with AMOS, 2nd edn., Routledge, New York.

Cabrera-Nguyen, P., 2010, 'Author guidelines for reporting scale development and validation results in the Journal of the Society for Social Work Research', Journal of the Society for Social Work and Research 1(2), 99-103. http://dx.doi. org/10.5243/jsswr.2010.8

Chen, J.S., Ching, R., Tsai, H.T. \& Kuo, Y.J., 2008, Blog effects on brand attitude and purchase intention, paper presented at the 5 th International Conference on Service Systems and Service Management, Melbourne, June.

Cooper, D.R. \& Schindler, P.S., 2006, Business research methods, 9th edn., McGraw-Hill Publishing Company, UK.

Coulter, K.S. \& Roggeveen, A., 2012, 'Like it or not: Consumer responses to word-ofmouth communication in on-line social networks', Management Research Review 35(9), 878-899. http://dx.doi.org/10.1108/01409171211256587

Darvell, M.J., Walsh, S.P. \& White, K.M., 2011, 'Facebook tells me so: Applying the theory of planned behaviour to understand partner-monitoring behaviour on Facebook', Cyberpsychology, Behaviour and Social Networking 14(12), 717-721. http://dx.doi.org/10.1089/cyber.2011.0035

Dittmar, H., Long, K. \& Meek, R., 2004, 'Buying on the internet: Gender differences in online and conventional buying motivations', Sex Roles 50(5/6), 423-444. http:// dx.doi.org/10.1023/b:sers.0000018896.35251.c7

Dodds, W.B., Monroe, K.B. \& Grewal, D., 1991, 'Effects of price, brand, and store information on buyers' product evaluations', Journal of Marketing Research 28, 307-319. http://dx.doi.org/10.2307/3172866

Erdogmus, I.E. \& Cicek, M., 2012, 'The impact of social media marketing on brand loyalty', Procedia - Social and Behavioural Sciences 58, 1353-1360. http://dx.doi. org/10.1016/j.sbspro.2012.09.1119

Facebook, 2015, Statistics, viewed 10 February 2015, from http://newsroom.fb.com/ company-info/

Field, A., 2013, Discovering statistics using IBM SPSS statistics, Sage, London.

Foxall, G.R. \& Goldsmith, R.E., 1994, Consumer psychology for marketing, Routledge, London.

Goldstuck, A., 2012, South African social media landscape 2012, viewed 2 September 2014 from http://www.worldwideworx.com/wp.../Exec-Summary-Social-Media-20121.pdf

Goldstuck, A., 2015, South African social media landscape report 2015, Fuseware and World WideWorx, Pinegowrie.

Gummerus, J., Liljander, V., Weman, E. \& Pihlström, M., 2012, 'Customer engagement in a Facebook brand community', Management Research Review 35(9), 857-877. http://dx.doi.org/10.1108/01409171211256578

Habibi, M.R., Laroche, M. \& Richard, M., 2014, 'The roles of brand community and community engagement in building trust in social media', Computers in Human Behaviour 37, 125-161. http://dx.doi.org/10.1016/j.chb.2014.04.016

Haferkamp, N., Eimler, S.C., Papadakis, A. \& Kruck, J.V., 2012, 'Men are from Mars, women are from Venus? Examining gender differences in self-presentation on social networking sites', Cyberpsychology, Behaviour and Social Networking 15(2), 91-98. http://dx.doi.org/10.1089/cyber.2011.0151

Hair, J.F., Jr, Black, W.C., Babin, B.J. \& Anderson, R.E., 2014, Multivariate data analysis, 7 th edn., Pearson Education Limited, Harlow.

Hodis, M.A., Sriramachandramurthy, R. \& Sashittal, H.C., 2015, 'Interact with me on my terms: A four segment Facebook engagement framework for marketers', Journal of Marketing Management 31, 1255-1284. http://dx.doi.org/10.1080/02 67257X.2015.1012535

Hooper, D., Coughlan, J. \& Mullen, M., 2008, 'Structural equation modelling: Guidelines for determining model fit', Electronic Journal of Business Research Methods 6(1), 53-60.

Hudson, S. \& Thal, K., 2013, 'The impact of social media on the consumer decision process: Implications for tourism marketing', Journal of Travel and Tourism Marketing 30(1-2), 156-160. http://dx.doi.org/10.1080/10548408.2013.751276

Kane, K., Chiru, C. \& Ciuchete, S.G., 2012, 'Exploring the eco-attitudes and buying behaviour of Facebook users', Amfiteatru Economic 14(31), 157-171.

Kaplan, A.M. \& Haenlein, M., 2010, 'Users of the world, unite! The challenges and opportunities of social media', Business Horizons 53, 59-68. http://dx.doi. org/10.1016/j.bushor.2009.09.003

Khang, H., Ki, E.J. \& Ye, L., 2012, 'Social media research in advertising, communication, marketing, and public relations, 1997-2010', Journalism \& Mass Communication Quarterly 89(2), 279-298. http://dx.doi.org/10.1177/1077699012439853

Kietzmann, J.H., Hermkens, K., McCarthy, I.P. \& Silvestre, B.S., 2011, 'Social Media? Get serious! Understanding the building blocks of social media', Business Horizons 54, 241-251. http://dx.doi.org/10.1016/j.bushor.2011.01.005

Kim, J.W., Choi, J., Qualls, W. \& Han, K., 2008, 'It takes a marketplace community to raise brand commitment: The role of online communities', Journal of Marketing Management 24(3-4), 409-431. http://dx.doi.org/10.1362/026725708X306167

Kline, R.B., 2011, Principles and practice of structural equation modelling, 3rd edn., Guilford Press, New York.

Kumar, V., Aksoy, L., Donkers, B., Venkatesan, R., Wiesel, T. \& Tillmans, S., 2010, 'Undervalued or overvalued customers: Capturing total customer engagement', Journal of Service Research 13(3), 297-310. http://dx.doi.org/10.1177/1094670510375602

Lei, P.W. \& Wu, Q., 2007, 'Introduction to structural equation modelling: Issues and practical considerations', Educational Measurement: Issues and Practice 26 33-43. http://dx.doi.org/10.1111/j.1745-3992.2007.00099.x

Lien, C. \& Cao, Y., 2014, 'Examining We Chat users' motivations, trust, attitudes, and positive word-of-mouth: Evidence from China', Computers In Human Behaviour 41, 104-111. http://dx.doi.org/10.1016/j.chb.2014.08.013 
Mangold, W.G. \& Faulds, D.J., 2009, 'Social media: The new hybrid element of the promotion mix', Business Horizons 52, 357-365. http://dx.doi.org/10.1016/ promotion mix', Busin
j.bushor.2009.03.002

McAlexander, J.H., Schouten, J.W. \& Koenig, H.F., 2002, 'Building brand community', Journal of Marketing 66, 38-54. http://dx.doi.org/10.1509/jmkg.66.1.38.18451

Mir, I.A., 2014, 'Effects of pre-purchase search motivation on user attitudes towards? Online social network advertising: A case of university students', Journal of Competitiveness 6(2), 42-55. http://dx.doi.org/10.7441/joc.2014.02.04

Muniz, A.M. \& O'Guinn, T.C., 2001, 'Brand community', Journal of Consumer Research 27, 412-432. http://dx.doi.org/10.1086/319618

Nusair, K. \& Hua, N., 2010, 'Comparative assessment of structural equation modelling in multiple regression research methodologies: E-commerce context', Tourism Management 31, 314-324. http://dx.doi.org/10.1016/j.tourman.2009.03.010

Omnicum Media Group (OMD), 2014, South Africa and Southern African development community media facts 2015, viewed 25 November 2014, from http://www.omd. co.za/media facts/FM $\% 20$ AdFocus $\% 20$ Media $\% 2$ Facts $\% 2028 \% 20$ November\%202014.pdf

Pallant, J., 2005, SPSS Survival manual: A step-by-step guide to data analysis using SPSS, 2nd edn., Allen \& Unwin, Crow's Nest, CO.

Pollard, E. \& Liebeck, H., 1994, The Oxford paperback dictionary, Oxford University Press, London.

Pöyry, E., Parvinen, P. \& Malmivaara, T., 2013, 'Can we get from liking to buying? Behavioral differences in hedonic and utilitarian Facebook usage', Electronic Commerce Research and Applications 12(4), 224-235. http://dx.doi.org/10.1016/ j.elerap.2013.01.003

Ryan, R.M. \& Deci, E.L., 2000, 'Intrinsic and extrinsic motivations: Classic definitions and new directions', Contemporary Educational Psychology 25(1), 54-67. http:// dx.doi.org/10.1006/ceps.1999.1020

Schumacker, R.E. \& Lomax, R.G., 2010, A beginner's guide to structural equation modelling, 3rd edn., Routledge, New York.

Socialbakers, 2013, South Africa Facebook statistics, viewed 10 June 2014, from http://www.socialbakers.com/facebookstatistics/south-africa

Spears, N. \& Singh, S.N., 2004, 'Measuring attitude toward the brand and purchase intentions', Journal of Current Issues \& Research in Advertising 26(2), 53-66. http://dx.doi.org/10.1080/10641734.2004.10505164
Steyn, P., Ewing, M.T., Van Heerden, G., Pitt, L.F. \& Windisch, L., 2011, 'From whence it came: Understanding source effects in consumer generated advertising', International Journal of Advertising 30(1), 13-160. http://dx.doi.org/10.2501/ija30-1-133-160

Suhr, D., 2006, The basics of structural equation modelling [tutorials], viewed 10 September 2014, from http://www.lexjansen.com/wuss/2006/tutorials/tut-suhr.pdf

Ullman, J.B., 2006, 'Structural equation modelling: Reviewing the basics and moving forward', Journal of Personality Assessment 87, 35-50. http://dx.doi.org/10.1207/ s15327752jpa8701_03

Ulusu, Y., 2010, 'Determinant factors of time spent on Facebook: Brand community engagement and usage types', Journal of Yasar University 18(5), 2949-2957.

Van Doorn, J., Lemon, K.N., Mittal, V., Nass, S., Doreèn, P., Pirner, P. \& Verhoef, P.C., 2010, 'Customer engagement behaviour: Theoretical foundations and research directions', Journal of Service Research 13(3), 253-266. http://dx.doi.org/ $10.1177 / 1094670510375599$

Vargo, S.L., 2009, 'Toward a transcending conceptualization of relationship: A servicedominant logic perspective', Journal of Business \& Industrial Marketing 24(5/6), 373-379. http://dx.doi.org/10.1108/08858620910966255

Vivek, S.D., Beatty, S.E. \& Morgan, R.M., 2012, 'Customer engagement: Exploring customer relationships beyond purchase', Journal of Marketing Theory and Practice 20(2), 122-146. http://dx.doi.org/10.2753/mtp1069-6679200201

WebAfrica, 2015, South Africa's popular social networks 2014, viewed 21 January 2015, from http://blog.webafrica.co.za/social-media-2/south-africas-popularsocial-media-networks-2014

Weinberg, B.D. \& Pehlivan, E., 2011, 'Social spending: Managing the social media mix', Business Horizons 54, 275-282. http://dx.doi.org/10.1016/j.bushor.2011.01.008

Wirtz, J., den Ambtman, A., Bloemer, J.M.M., Horváth, C., Ramaseshan, B., van de Klundert, J., Gurdan Canli, Z. \& Kandampully, J., 2013, 'Managing brands and customer engagement in online brand communities', Journal of Service Management 24(3), 223-244. http://dx.doi.org/10.1108/09564231311326978

Zaglia, M.E., 2013, 'Brand communities embedded in social networks', Journal of Business Research 66(2), 216-223. http://dx.doi.org/10.1016/j.jbusres.2012.07.015

Zhang, Y. \& Leung, L., 2014, 'A review of social networking service (SNS) research in communication journals from 2006 to 2011', New Media \& Society 1-18 http:// dx.doi.org/10.1177/1461444813520477 